IJLRES - International Journal on Language, Research and Education Studies

ISSN: 2580-6777 (p); 2580-6785 (e)

DOI: $10.30575 / 2017 /$ IJLRES-2018050808

Vol. 2, No. 2, 2018

Page: $237-250$

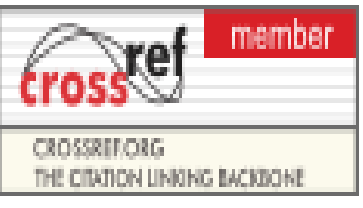

\title{
THE ISLAMIC VALUES BASE NATURAL SCIENCES INSTRUCTIONAL MATERIALS DEVELOPMENT MODEL
}

\author{
Rusydi Ananda \\ State Islamic University of North Sumatra, Indonesia \\ rusdiananda.1972@gmail.com
}

\begin{abstract}
The object of this research was to develop of instructional materials model of the natural science based on Islamic values. Expansion of this research had been implementing the research method of Research \& Development. The results of the validation of expert's team concluded that the model meets the instructional materials designed just and proper procedures were used. Based on the results of the feasibility test was then followed by one-to-one learner, small group and field trials. Then test the effectiveness of the model were by comparing the results of pretest and posttest and were analyzed using $t$-test. It was concluded that the instructional materials products give a real effect on student learning outcomes.
\end{abstract}

Keywords: Instructional materials, Natural Science, Islamic values.

\section{INTRODUCTION}

The dynamics and flexibility that occur in higher education institutions both general higher education and religious higher education are a necessity. In this case the process of growth and development of higher education institutions cannot be separated from internal and external factors that encompass it. Internal factors related to the dynamics and flexibility that occur within the institution of higher education while external factors related to the dynamics and flexibility of developments that occur outside the higher education institution.

Observing the current condition of education so it is needed extra seriousness of academic community of Tarbiyah and Teachers of State Islamic University North Sumatra to think and act in improving the quality of education and learning. This rationale is based on: (1) the changing condition of the society of North Sumatra, as well as the lecture system on campus that is different from the previous period; (2) the organizational reason that the academic community of UIN North Sumatra considers this learning pattern so far as something that has been established. Such this mindset makes the academic community less innovative in learning; (3) the paradigm shift of 


\section{Rusydi Ananda}

learning approach from teacher center to student center; and (4) the development of the latest scientific knowledge.

Therefore, systematic and systemic assessment is required in relation to instructional design based on the study of educational technology. In this case the urgency of learning design are: (1) learning is a process that aims, the more complex goals to be achieved in learning the more complex the learning process that must be designed; (2) learning is a process of cooperation involving various components that interact with each other; and (3) the learning process will be more effective when utilizing various facilities and infrastructure.

Referring to the above thoughts, so it is necessary to develop Basic Learning Materials (IAD) based on Islamic values with the following assumptions: (1) the development of learning materials can be used as learning resources that can facilitate the students to get the purpose of IAD subject; (2) the development of IAD learning materials becomes important when viewed from the perspective of easy of learning and improvement of the acquisition of student learning outcomes due to the development of learning materials designed in order to fulfill the needs of the characteristics of students who are studying in Islamic universities; (3) the development of this learning material becomes important when viewed from the perspective of IAD course learner as it is not yet available the subject matter that is based on Islamic values; and (4) the development of this learning material becomes important when viewed from the perspective of institutions that produce products that are in accordance with their characteristics so as to reinforce the existence of institutions as universities that concentrate to Islam.

\section{LITERATURE REVIEW}

The main theories used in the learning materials development model are the elaboration of several theories of ASSURE models, ADDIE models, Dick models, Carey and Carey, Seels \& Glasgow models, Smith and Ragan models, Shambaugh and Magliaro models, Suparman instructional development models. In this case, regardless of model form, there are 6 (six) main characteristics as described by Reiser and Dempsey; (1) centered on learners; (2) goal-oriented; (3) focusing on improving performance; (4) 
learning outcomes can be measured in a valid and reliable way; (5) empirical, repeatable and self-corrected; and (6) team effort ${ }^{1}$.

Rothwal and Kazanas described the six steps of developing learning materials: (1) preparing the outlines of instructional materials; (2) conducting research; (3) test the available learning materials; (4) compile or modify the materials available; (5) providing and making learning materials; and (6) selecting or providing learning activities².

Furthermore, related to Islamic values, Qardhawy describes the four pillars of values in Islam namely: aqidah, worship, morals, and legislation/law ${ }^{3}$. Az-Zuhaili describes the four elements of important values in Islam: (1) faith in God, angels, books, apostles, doomsday and destiny; (2) mandatory worship services and pillars of religion as a means of law in unifying the community; (3) morals used as guidance and mentors of the soul, education for the behavior and self-correction of the journey of life; and (4) wise laws and there is a relationship of attachment between legal products and judges ${ }^{4}$.

These Islamic values in relation to the development of the IAD learning models are not in the development of IAD science itself but on the exposure of Islamic perspectives on the concepts contained in the IAD and provide values in the learning process (values to guide learning process) so that can provide a meaningful contribution to the development of learning within the PTAIN environment.

\section{METHODOLOGY}

The development of a model of learning materials designed is carried out by applying research and development (R \& D) from Gall, Gall and Borg with the following steps: identifying learning objectives, learning analysis, characteristic analysis of learners and the context of learning, writing specific learning objectives developing assessment instruments, developing learning strategies, developing and selecting

\footnotetext{
${ }^{1}$ Robert A Reiser and John V Dempsey,. Trends And Issues In Instructional Design And Technology. New Jersey: Pearson Merril Prentice Hall, 2007. P. 13

2 William J Rothwell and H.C Kazanas,. Mastering The Instructional Design Process: A Systematic Appproach. Third Edition. San Fransisco, Pfeiffer, 2004. P. 247

${ }^{3}$ Yusuf Qardhawy, Madkhal Lima'rifatil Islam, Alihbahasa: Setiawan Budi Utomo, Pengantar Kajian Islam. Jakarta: Pustaka Al-Kautsar, 1997. P. 55

${ }^{4}$ Wahbah Az-Zhuhaili,. Al-Qur'an Al-Karim Bunaituhuu, Al-Tassyirriyatwa Khashaa Isluhu AlHadllariyat, Alihbahasa: M. Thohirdan Team Titian Ilahi. Al-Qur'an dan Paradigma Peradaban. Yogyakarta: Dinamika, 1996. P. 203
} 
teaching materials designing and developing formative evaluations, revising designs, designing and developing summative evaluations ${ }^{5}$.

\section{FINDINGS AND DISCUSSION}

\section{Development of Learning Materials.}

Developing a model of IAD-based learning materials based on Islamic values begins with the activity of selecting learning materials derived from existing learning resources tailored to the development needs of the designed learning materials. In other words, the designed learning materials are a compilation of existing learning resources, namely the literature related to the concept of IAD from the perspective of science and literature related to the perspective of Islam on the concepts of IAD are taken from the Qur'an, hadith, and tsurats of Muslim scholars and Muslim science.

After learning resources are collected as materials for the development of learning materials, then the next production is done with attention to the principle of accuracy and conformity with the theme of the discussion contained in the development of learning materials. Accuracy and conformity are prioritized in the preparation of learning materials because of their designation to lecturers and students as guidance in the implementation of lectures.

\section{Model Feasibility by Expert Team}

The feasibility test by the expert team is to look at the feasibility of IAD-based instructional products based on Islamic values, in which case the design feasibility test is validated by instructional design experts, materials experts and linguists. Expert team validation results of IAD learning materials can be seen in the following table:

Table 1. Recapitulation of Feasibility Test Results By Expert Against Learning Material Products

\begin{tabular}{|l|l|c|l|}
\hline No & Group & Mean Scores & Categories \\
\hline 1 & Intructional Design Expert & 3,27 & Eligible without revision \\
\hline 2 & IAD Material Expert & 3,29 & Eligible without revision \\
\hline 3 & Muslim Material Expert & 3,30 & Eligible without revision \\
\hline 4 & Linguists & 3,52 & Eligible without revision \\
\hline \multicolumn{2}{|c|}{ Average Score Cumulative } & $\mathbf{3 , 3 4}$ & Eligible without revision \\
\hline
\end{tabular}

${ }^{5}$ Gall, Meredith D., Gall, Joyce P., dan Borg, Walter R. Educational Research. Eight Edition. Boston: Pearson Education, Inc. 2007 
The Islamic Values Base Natural Sciences Instructional Materials Development Model DOI: 10.30575/2017/IJLRES-2018050808

Referring to the above table it can be seen that the cumulative score of 3.34 of the results of expert feasibility tests of IAD-based learning materials products based on Islamic values are in a decent category without revision. This means that the product of the developed learning material reflects the level of eligibility to use. 


\section{Rusydi Ananda}

\section{Field Test Results}

\section{a. Individual Trial}

Individual test results on learning materials products can be seen in the following table:

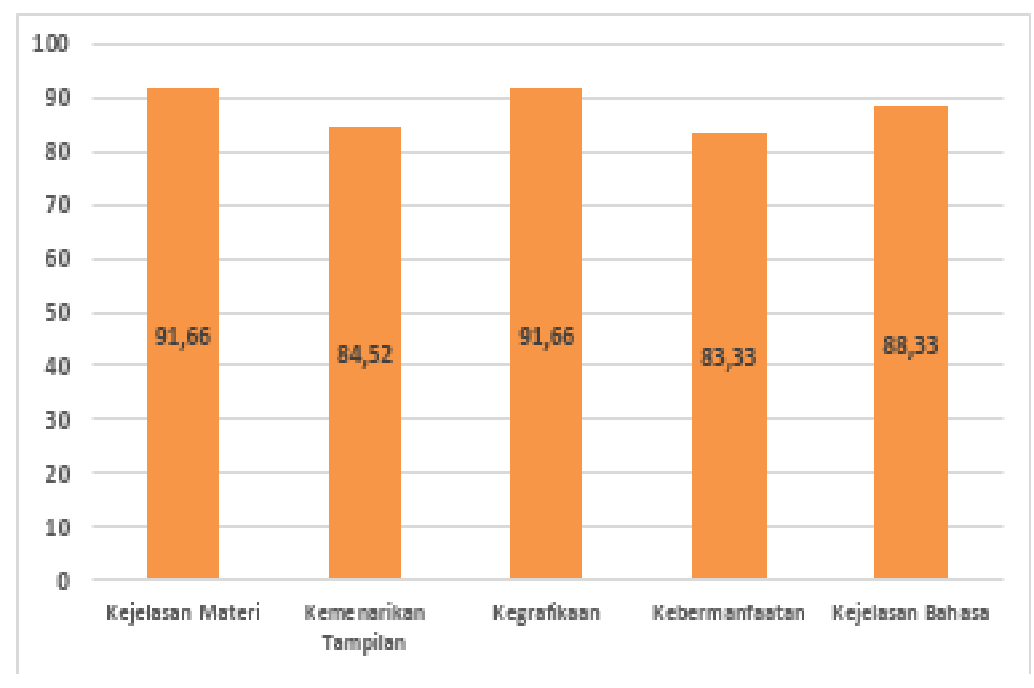

\section{Graph 1. Individual Test Results}

Based on the above data can be seen the results of individual testing as follows: Material Clarity Aspects are with 3 (three) indicators reached the average feasibility level 3,66 or 91,66. This figure is in a very decent category. Display Attractiveness Aspects are with 7 (seven) indicators reach an average feasibility level of 3.38 or 84.52. Graphic Aspects are with 5 (five) indicators reached the average feasibility level 3,66 or 91,66. Utilization Aspects are with 5 (five) indicators reaches an average feasibility level of 3.33 or 83.33. Language Clarity Aspects with 5 (five) indicators reaches an average feasibility level of 3.53 or 88.33 . This figure is in a decent category without revision.

\section{b. Small group trial}

Results of small group testing of learning materials products can be seen in the following graph: 


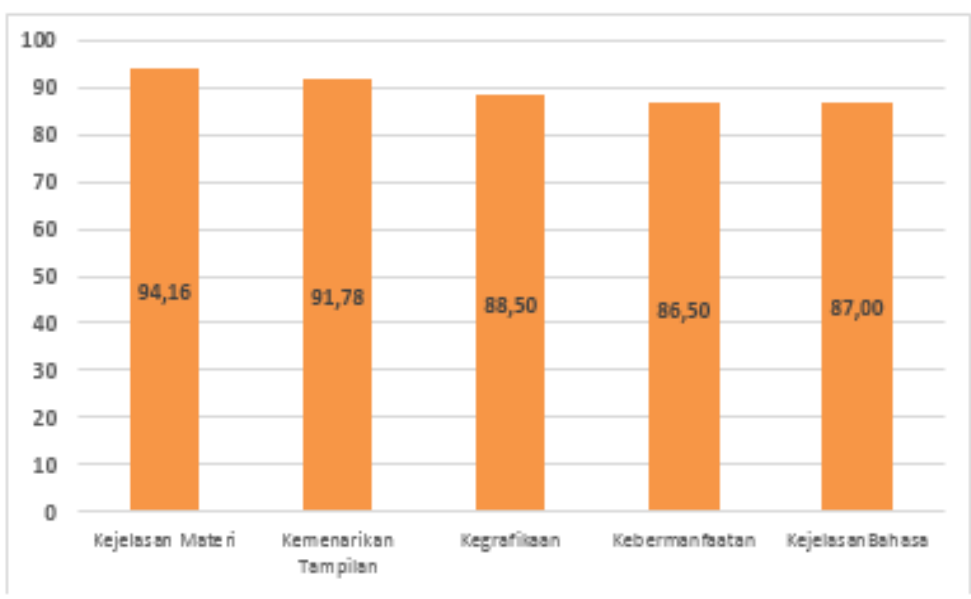

\section{Graph 2. Small Group Test Results}

Based on the above data it can be seen: Material Clarity Aspects are with 3 (three) indicator reaches average feasibility level 3,76 or 94,16 . This figure is in a very decent category. Display Attractiveness Aspects are with 7 (seven) indicators reach an average feasibility level of 3.67 or $91.78 \%$. This figure is in a very decent category. Graphic Aspects are with 5 (five) indicators reach the average feasibility level 3.54 or 88.50 . This figure is in a decent category without revision. Utilization Aspects are with 5 (five) indicators reach an average feasibility level of 3.46 or 86.50 . This figure is in a decent category without revision. Language Clarity Aspects are with 5 (five) indicators reach an average feasibility level of 3.48 or 87.00 . This figure is in a decent category without revision.

\section{c. Field Group Trials}

The results of field trials of product learning materials can be seen in the following graph:

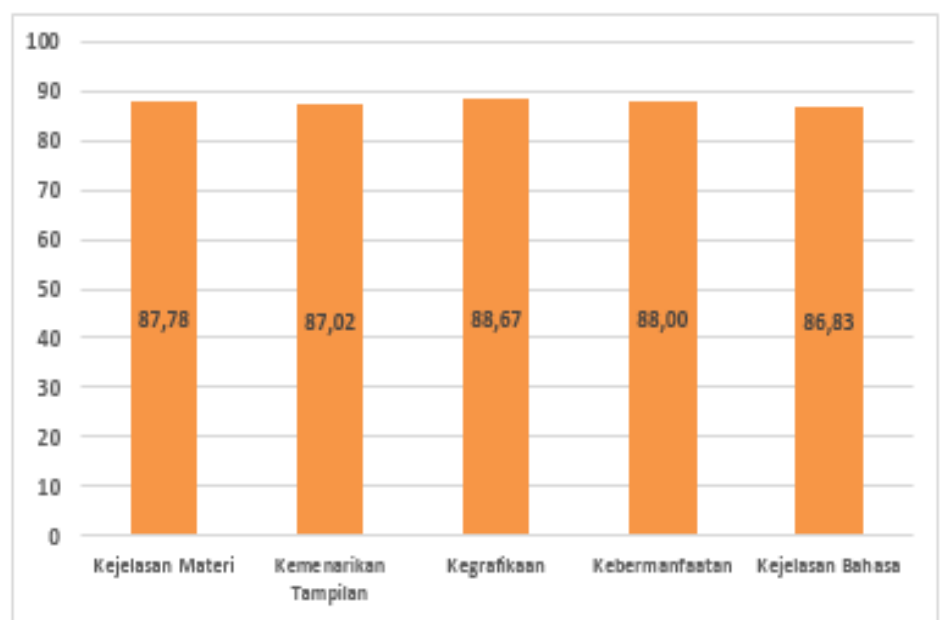

Graph 3. Field Field Trial Results 


\section{Rusydi Ananda}

In general, the results of field trials of IAD-based learning materials based on Islamic values show a score of 87.60 and are in a decent category without revision. This means that the product of the developed learning material reflects the level of eligibility to use. Based on data obtained from field trial results, that IAD learning materials products based on Islamic values other than the learning design for individual activities in this case students personally study the material also designed learning for group activities.

\section{Model Effectiveness Test}

The effectiveness test of IAD learning materials product is evaluated learning result obtained through pre-test and post-test. Pre-test in this case is the score of the subject's acquisition of teaching materials to be taught while the post-test is the score of the subject's acquisition of teaching materials that have been taught. Based on the results of statistical tests obtained price $t$ count 19.3 and $t$ table price at $\alpha=0.05$ is 2.039. Because the price of $t$ count $>t$ table price then Ho is rejected, it can be concluded that IAD learning materials based products Islamic values give a real effect on student learning outcomes.

\section{Discussion}

Basic learning materials based on Islamic values are intended for face-to-face lecture. Where in the face-to-face lecture, the lecturers serve as lecturers and students act as learners who learn from lecturers and from developed learning materials. In this case Suparman describes the following: (1) learning materials in the form of a compilation of learning resources available and relevant to the strategy of learning that is prepared; (2) assessment of learning outcomes in accordance with the learning objectives; (3) teaching guidance on how to use the compilation material; and (4) learners' guidance on how to learn and follow lesson activities under the teaching of teachers ${ }^{6}$.

IAD-based learning materials products based on Islamic values are used to facilitate lectures so in fact it is in line with the spirit contained in educational technology itself. In this case the Association for Educational and Technology (AECT), as cited

${ }^{6}$ M. Atwi Suparman, Desain Instruksional Modern, Panduan Para Pengajar dan Inovator Pendidikan. Jakarta: Erlangga, 2012.p. 287 
Januszweski and Molenda (2008: 1) defines educational technology, namely: "study and ethical practice to facilitate learning and improve performance through the creation, use, and management of processes and resources ${ }^{7}$.

Referring to the above AECT concepts related to facilitating learning, and improving performance, product learning materials, lecturer guides and student guides can facilitate learning and performance improvement as defined in the AECT education technology definition which can be described as follows:

a. This learning materials product can expand student access to IAD learning resources not only from the perspective of science but also equipped with Islamic concepts. Moreover the product of this learning material is developed in accordance with the needs of students who study at Islamic universities.

b. Through the design of paperwork assignments conducted individually or groups that discuss the themes of discussion in the IAD course make students actively study. Individual assignments in the form of book annotations make students actively working on their reports because students know the criteria that must be met in the book's annotation report. Likewise with group assignments, there is also an appraisal format linked to the paper itself and an assessment of the presentation, which enables students to be actively involved in the course.

c. The product of learning materials and student guidance can encourage student personalization that refers to the competence that is required in IAD lecture because of the availability of learning materials and student guidance that can lead the students in achieving competence.

d. The adequacy of IAD materials both from the perspective of science and Islamic perspectives contained in the model of learning materials hence more maximizing student time in terms of finding themes of IAD discussion from various learning sources.

e. The product of this learning material helps students to independently manage their learning. Students can more effectively be independent in mastering learning materials and more able to learn at their own pace of learning because of the availability of easily accessible learning resources.

${ }^{7}$ Alan Januszweski and Michael Molenda,. Educational Technology, A Definition with Commentary (New York: Lawrence Erlbaum Assocuates, 2008). P. 1 


\section{Rusydi Ananda}

f. This learning materials product helps students to be more effective in mastering the competence of learning because the theme of the discussion required in IAD lectures in it both from the perspective of science and Islamic perspective.

This learning materials product becomes the guideline in conducting IAD lecture especially from user perspective (University student) in understanding IAD teaching materials. In other words the product of this learning material can be a learning resource for students. In the perspective of learning resources, IAD learning materials product is a planned learning source (by design) in the form of printed materials. Related to this AECT explaination that learning resources can be grouped into two parts: (1) planned learning resources (by design), ie all learning resources that have been specifically developed as a component of the instructional system to provide learning facilities which is directed and formal; and (2) learning resources because it is utilized (by utilized) is sources that are not specifically designed for learning purposes but can be found, applied and used for learning purposes ${ }^{8}$.

The function of IAD learning materials products based on Islamic values as learning resources is to help students in achieving optimal learning outcomes due to provide stimuli to learn and accelerate understanding and mastery of knowledge learned. This is confirmed Siregar and Nara (2010: 128) about the benefits of learning resources are: (1) can provide a more concrete and direct learning experience; (2) may present something that is impossible to be held, visited or viewed directly; (3) can add and expand the existing science horizons in the classroom; (4) may provide accurate, upto-date information; (5) can help solve the problem of education both macro and in micro environment; (6) can provide positive motivation, especially if properly arranged and designed; and (7) can be stimulated to think more critically, stimulate to be more positive and stimulate to grow further'.

Through the completeness of the material contained in the learning materials then students as users can be studied independently. In this case students are expected to actively and participatively to develop themselves in acquiring knowledge without having to be tied to the exposure of course tutor but can find science. For that required

\footnotetext{
${ }^{8}$ Association for Educational Communication and Technology. The Definition of Educational Terminology. Alihbahasa: Arief S. Sadiman dkk. Jakarta: Rajawali 1986. P. 29

9 Eveline Siregar and Hartini.Nara, Teori Belajar Dan Pembelajaran. Bogor: Ghalia Indonesia, 2010. P. 128
} 
internal motivation, willingness, seriousness, tenacity, discipline, responsibility and of course a great curiosity in seeking knowledge.

Further interesting things to be exposed from the record of field test results is that IAD learning materials products based on Islamic values developed are guidance tools for lecturers and guides for students. In this case some field test subjects stated the need to present detailed descriptions of the assigned tasks to the students, including the rubric and assessment criteria. Following this in the student manual, the developer has listed it in the student manual, so that in the lecture the student can see the signs related to the assignment and assessment rubric.

It is recognized that IAD-based learning materials based on Islamic values have the following limitations: (1) the product of this learning material is not the only source of learning for the students due to the limited exposure of the material in it, in addition to using the product of this learning material then students are expected to use other learning resources to complement each other; (2) the product of this learning material is designed in the form of printed learning materials, as it is known that printed learning materials have limitations in terms of linear material exposure so that it tends to be used passively; and (3) this research was conducted on the students of FITK UIN of North Sumatra with unique characteristic and context which is thick with Islamic nuance. Therefore the product of instructional material is only appropriately used with such characteristics and context.

\section{CONCLUSION}

In general, this research has reached its goal of finding models of development of learning materials based on Islamic values developed for lectures at Islamic universities. The learning materials development model is developed from the analysis of the learning needs analysis required in the implementation of IAD lectures in Islamic universities that have unique characteristics and different from other public universities.

Learning material development model developed through stages: (1) preliminary study that is learning needs analysis; (2) stage 1 pre-development of learning materials include: writing general learning objectives, conducting learning analyzes, analyzing student characteristics and learning context, writing specific learning goals, developing assessment instruments, and developing learning strategies; (3) stage 2 development of learning materials includes the selection of materials and 


\section{Rusydi Ananda}

production of learning materials. Sources of learning are selected in the form of basic scientific science concepts, al-Qur'an, Hadith and tsurats of Muslim scholars and Muslim scientists; (4) stage 3 experimentation of learning materials product; and (5) the final product of learning materials. During the process of phase 1 to stage 3 revisions are made to refinement.

During the process of developing learning materials until the final product has been passed through the process and development of learning materials from the needs analysis, planning, design, evaluation and testing stages. In order to see the feasibility of the study materials, the validation done by the expert team, in this case the team of experts stated that the product of learning materials has been done in accordance with the appropriate methods and procedures that are suitable for use. Then followed by oneto-one learner test, small group test and field group test. Furthermore, the learning material product is tested for effectiveness.

The process and dynamics in designing the products of natural learning materials based on Islamic values are inseparable from the limited scientific approach to the development of learning materials, but are related to other scientific fields such as the science of instructional design, research methodology, communication science, and Islamology.

The aspect of the renewal of the product of learning materials as a contribution to the development of scholarship is a learning material designed for the learning needs of Islamic universities in the design process through the learning needs assessment phase, the characteristics of learners, designing objectives, developing assessment instruments, developing learning strategies including sequence of learning, media, media and time allocation. In other words, the renewal of the product of this learning material is to fill the "empty space" in IAD lectures that are based on the concept of science only. The empty space is a blend of Islamic concepts and concepts of IAD materials.

\section{BIBILIOGRAPHY}

Association for Educational Communication and Technology. The Definition of Educational Terminology. Alihbahasa: Arief S. Sadiman dkk. Jakarta: Rajawali 1986. 
Az-Zhuhaili, Wahbah. Al-Qur'an Al-Karim Bunaituhuu, Al-Tassyirriyatwa Khashaa Isluhu AlHadllariyat, Alihbahasa: M. Thohirdan Team Titian Ilahi. Al-Qur'an dan Paradigma Peradaban. Yogyakarta: Dinamika, 1996.

Dick, Walter., Carey, Lou., dan Carey, James O. The Systematic Design of Instruction. Seventh Edition. New Jersey: Pearson, 2009.

Gall, Meredith D., Gall, Joyce P., dan Borg, Walter R. Educational Research. Eight Edition. Boston: Pearson Education, Inc. 2007.

Gustafson, Kent L. dan Branch, Robert Maribe. Survey of Instructional Development Models. Syracuse New York: ERIC Clearinghouse on Information \& Technology, 2002.

Huberman, A.M., dan Miles, M.B.Qualitative Data Analysis: A Sourcebook of New Methods. Baverly Hills, California: Sage, 1984.

Januszweski, Alan.,danMolenda, Michael. Educational Technology, A Definition with Commentary (New York: Lawrence Erlbaum Assocuates, 2008)

Majid, Abdul. Perencanaan Pembelajaran. Bandung:RemajaRosdakarya, 2005.

Prawiradilaga, Dewi Salma. Prinsip Disain Pembelajaran. Jakarta: Kencana Prenada Media Group, 2007.

Qardhawy, Yusuf. Madkhal Lima'rifatil Islam, Alihbahasa: Setiawan Budi Utomo, Pengantar Kajian Islam. Jakarta: Pustaka Al-Kautsar, 1997.

Reiser, Robert A., dan Dempsey, John V. Trends And Issues In Instructional Design And Technology. New Jersey: Pearson Merril Prentice Hall, 2007.

Richey, Rita C., Klein, James D., dan Tracey, Monica W. The Instructional Design Knowledge Base, Theory, Research And Practice. New York: Routledge, 2011.

Rothwell, William J., dan Kazanas, H.C. Mastering The Instructional Design Process: A Systematic Appproach. Third Edition. San Fransisco, Pfeiffer, 2004.

Siregar, Eveline., dan Nara, Hartini. Teori Belajar Dan Pembelajaran. Bogor: Ghalia Indonesia, 2010.

Snelbecker, Glenn E. Learning Theory, Instructional Theory, And Psychoeducational Design. New York: McGraw Hill, 1974.

Suparman, M. Atwi. Desain Instruksional Modern, Panduan Para Pengajar dan Inovator Pendidikan. Jakarta: Erlangga, 2012.

Yaumi, Muhammad. Prinsip-Prinsip Desain Pembelajaran. Jakarta: Kencana Prenada Media Group, 2013. 


\section{Rusydi Ananda}

